\title{
THE EXPRESSION OF NUSANTARAN ARCHITECTURE IN SESAT AGUNG ARCHITECTURE
}

\author{
${ }^{1}$ Nadine Noor Adhitya Putri, ${ }^{2}$ Indri Astrina, ST., MA \\ 1 Student in the Bachelor's (S-1) Study Program in Architecture \\ at Parahyangan Catholic University \\ ${ }^{2}$ Senior lecturer in the Bachelor's (S-1) Study Program in Architecture \\ at Parahyangan Catholic University
}

\begin{abstract}
As a visual language, architectural expressions can be understood through arrangements of its elements with certain patterns or techniques. According to Rob Krier (1988), the assessment of geometric expressions cannot be separated from the composition of architectural forms, including proportion, rhythm, ornament, shape, material, color and texture. Along the way, Tulang Bawang Barat, which was later abbreviated as Tubaba, became a stopover for migrants from various regions. Regent Umar Ahmad pursued the construction of Tulang Bawang Barat by building a mosque and a convention hall to fill the empty fields in Tulang Bawang Barat. The architectural expression of Balai Adat Sesat Agung - with its modernity - considered as success in reproducing historical and cultural identity of Nusantaran architecture.

In identifying the expressions of Nusantaran architecture, the analysis of Sesat Agung architecture is carried out in three areas: site, building, and structure. Through descriptive-analytical methods, this research begins by formulating the properties and compositions of Nusantaran architecture expressions forming through related theories, including Nusantaran architectural theory, concepts of properties and composition, and anatomy of architecture theory. Furthermore, the properties and composition of Sesat Agung are studied to identify the expressions of Nusantaran architecture which manifested in the architecture of the Balai Adat Sesat Agung. This study found that the architectural expression of the Sesat Agung has printed a new architectural identity in Tulang Bawang Regency. However, regardless of the form and the aesthetics it carries, one thing that is missing from Sesat Agung architecture is its spatial quality.
\end{abstract}

Key Words: expression, Nusantaran architecture, Sesat Agung.

\section{EKSPRESI KENUSANTARAAN PADA BALAI ADAT SESAT AGUNG - TULANG BAWANG BARAT}

\author{
${ }^{1}$ Nadine Noor Adhitya Putri, ${ }^{2}$ Indri Astrina, ST., MA \\ ${ }^{1}$ Mahasiswi S1 Program Studi Arsitektur Universitas Katolik Parahyangan \\ ${ }^{2}$ Dosen Pembimbing S1 Program Studi Arsitektur Universitas Katolik Parahyangan
}

\begin{abstract}
Abstrak - Sebagai bahasa visual, ekspresi dalam arsitektur dapat dipahami melalui bentuk fisik yang disusun dengan pola atau teknik tertentu. Menurut Rob Krier (1988), penilaian terhadap ekspresi geometrik tidak terlepas dari komposisi selubung, meliputi proporsi, irama, ornamen, bentuk, material, warna, dan tekstur. Dalam perjalanannya, Tulang Bawang Barat yang kemudian disingkat Tubaba menjadi tempat persinggahan bagi pendatang dari pelbagai daerah. Bupati Umar Ahmad meniti pembangunan Tulang Bawang Barat dengan mendirikan masjid dan balai adat untuk mengisi ladang-ladang eks-proyek transmigrasi. Ekspresi arsitektur Balai Adat Sesat Agung yang kental akan semangat kebaruan dianggap berhasil mereka ulang jejak sejarah dan budaya.

Dalam menemukenali ekspresi kenusantaraan, pencermatan atas arsitektur Sesat Agung dilakukan dalam tiga lingkup: tapak, bangunan, dan struktur. Dengan metode deskriptif-analitis, penelitian ini diawali dengan merumuskan properti dan komposisi pembentuk ekspresi kenusantaraan melalui teori-teori terkait, antara lain teori arsitektur Nusantara, konsep properti dan komposisi, dan teori anatomi bangunan. Selanjutnya, properti dan
\end{abstract}

${ }^{1}$ Corresponding Author: mail.nadinenoor@gmail.com 
komposisi pada objek penelitian dikaji untuk menemukenali ekspresi kenusantaraan yang terwujud pada arsitektur Balai Adat Sesat Agung. Penelitian ini menemukan bahwa ekspresi arsitektur Sesat Agung telah mencetak identitas arsitektur baru di Kabupaten Tulang Bawang. Akan tetapi, terlepas dari bentuk dan estetika yang disandangnya, satu hal yang lepas dari arsitektur Sesat Agung ialah kualitas spasial.

Kata Kunci: ekspresi, arsitektur Nusantara, Sesat Agung.

\section{PENDAHULUAN}

Kancah arsitektur Indonesia tengah diramaikan dengan predikat "kekinian", "mengkinikan", dalam wacana populer "Arsitektur Nusantara Mengkini”. Semangat dalam mengkinikan arsitektur Nusantara kian membara. Kini, pelbagai bangunan publik di Indonesia berlomba-lomba untuk menampilkan ciri kelokalannya. Hal ini dibuktikan dengan keinginan arsitek untuk berkarya di daerah. Bangunan dengan fungsi publik seperti tempat peribadatan, bandar udara, sekolah, pasar, dan balai dirancang dengan gelora Arsitektur Nusantara.

Kabupaten Tulang Bawang Barat lahir pada tahun 2008 bersama dua kabupaten lainnya. Atas perintah Bupati Umar Ahmad, agenda pembangunan Tubaba tidak terbatas pada lingkup ekonomi dan infrastruktur saja, namun turut membangun sumber daya manusia melalui kesenian dan kebudayaan. Pemerintah Kabupaten Tulang Bawang Barat - disingkat Tubaba menggandeng arsitek dan pegiat seni untuk membangun masa depan Tubaba dengan identitas baru dari masa lalu.

Dari sembilan rangkaian pembangunan di Tubaba, Balai Adat Sesat Agung merupakan salah satu bangunan kontemporer yang memelopori arah baru pembangunan Tubaba. Berdiri di atas lahan kosong yang semula berupa rawa-rawa dan perkebunan karet, Sesat Agung telah mencetak sosok arsitektur baru di Tubaba. Ragam perhelatan kesenian mapun keagamaan telah dilangsungkan di Sesat Agung. Tak hanya sebagai destinasi transmigran dan lahan perkebunan karet, Kabupaten Tulang Bawang Barat kini menjadi salah satu destinasi pariwisata di Indonesia. Dengan ini, rumusan masalah penelitian adalah mengungkap ekspresi kenusantaraan sebagai perwujudan arsitektur Nusantara pada arsitektur Sesat Agung.

Tujuan dari penelitian ini adalah menemukenali ekspresi kenusantaraan pada arsitektur Sesat Agung. Ruang lingkup penelitian dibatasi pada aspek pembentuk ekspresi kenusantaraan dengan penekanan pada properti dan komposisi yang mencakup aspek tapak, bangunan, dan struktur.

\section{KAJIAN TEORI}

\subsection{STUDI LITERATUR EKSPRESI KENUSANTARAAN}

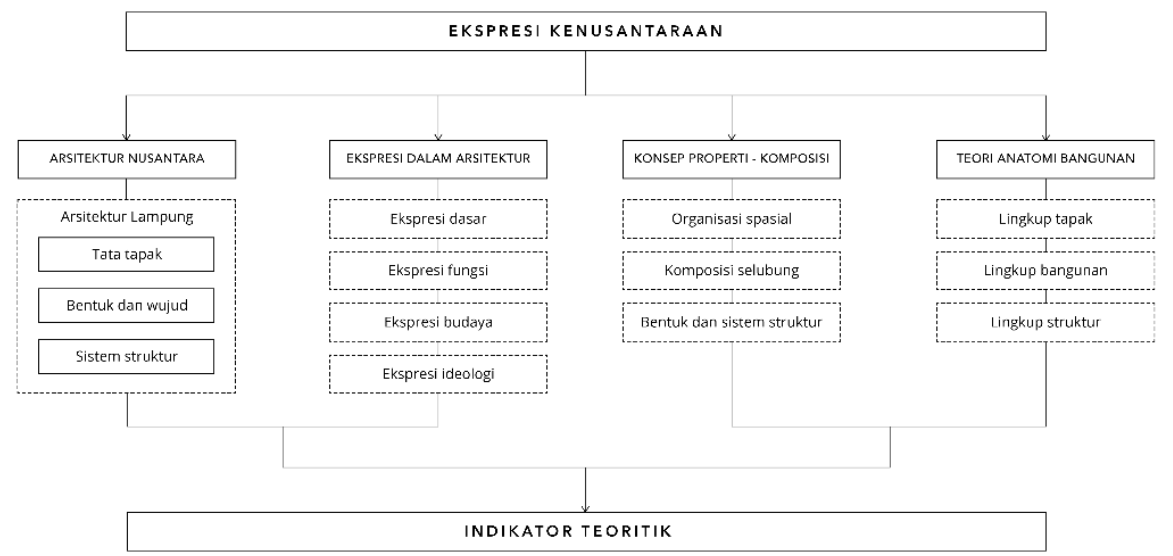

Gambar 1 Kerangka teoritik 
Teori yang digunakan dalam penelitian ini adalah teori arsitektur Nusantara oleh Josef Prijotomo (2018), yang membagi landasan pengetahuan arsitektur Nusantara menjadi tiga. Pertama, lingkungan binaan merupakan sebuah kerja dan karya pikir. Kedua, berkaitan dengan iklim tropis lembab di Nusantara. Dan yang terakhir berhubungan dengan kebaharian Nusantara. Dalam merumuskan matriks pembentuk ekspresi kenusantaraan, studi pustaka terkait properti dan komposisi arsitektur nusantara dibagi dalam tiga lingkup menurut teori anatomi arsitektur (Salura, 2018). Menurut Salura (2018), properti mencakup bentuk dasar fisik beserta karakteristiknya. Sementara itu, komposisi dibedakan berdasarkan posisi dan susunan antar objeknya. Sebagai pendukung, teori arsitektur yang digunakan adalah komposisi selubung (Krier, 1988), organisasi spasial (Ching, 1979; Krier, 1988), dan bentuk dan sistem struktur (Schodek, 2001).

\subsubsection{ARSITEKTUR NUSANTARA}

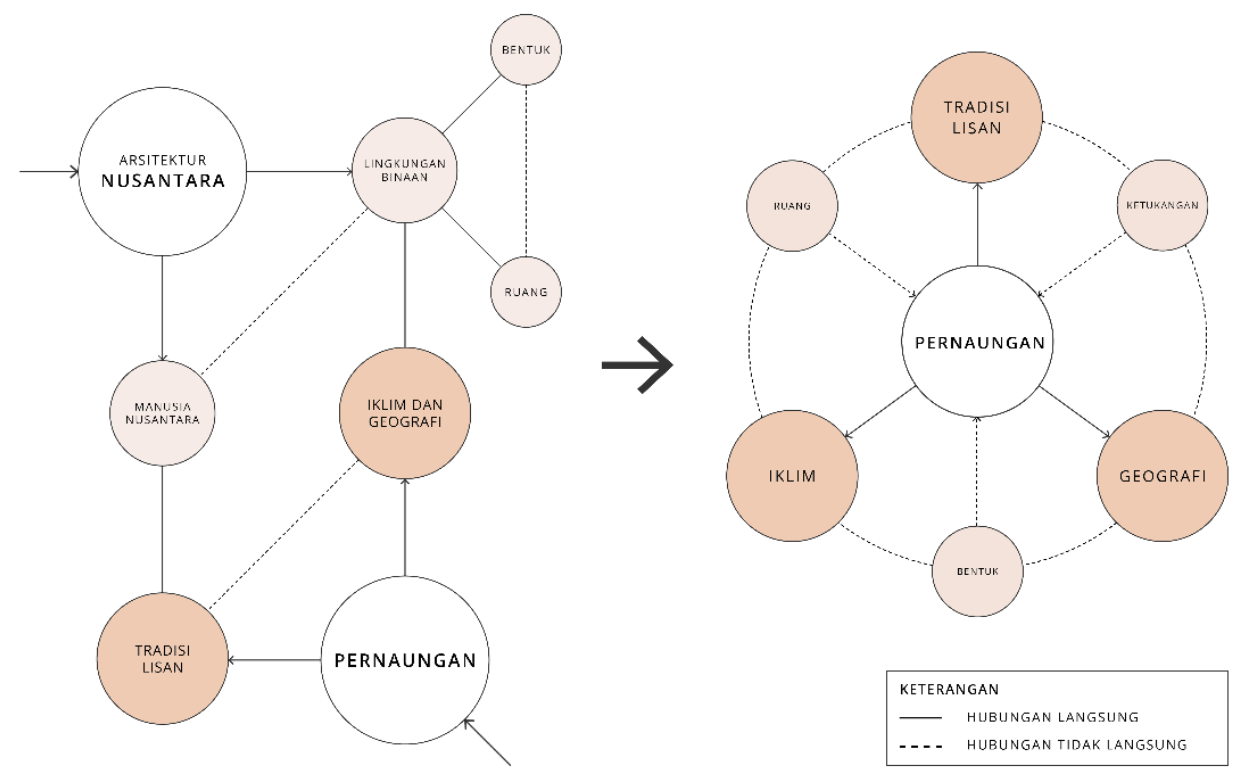

Gambar 2 Kerangka pengetahuan arsitektur Nusantara

Manusia Nusantara menganut tradisi lisan, yakni pewarisan ilmu pengetahuan yang dilakukan secara turun-temurun melalui kegiatan pemagangan, mitos, ritual, cerita rakyat, dan benda - salah satunya arsitek tur. Meskipun begitu, pengetahuan arsitektur Nusantara adalah ilmu pengetahuan dalam disiplin arsitektur, maka, yang menjadi fokus utama adalah arsitekturnya. Dalam konteks ini, arsitektur sendiri merupakan ilmu rancang bangun yang mencipta dan merekayasa di dalam tataran ruang fisik dan waktu. Maka, aspek-aspek tersebut memiliki kesempatan untuk berbeda bukan? Prijotomo (2008) beranggapan bahwa arsitektur berbahasa melalui rupa, yakni bentuk dan wujud. Oleh karena itu, secara visual arsitektur harus mampu dibaca oleh panca-indra khususnya indra penglihatan. Oleh sebab itu, pengkajian terhadap arsitektur dilakukan pada aspek bangunan (elemen pelingkup dan struktur-konstruksi) dan aspek tapak (lanskap dan tata massa). Selanjutnya, karena bangunan itu didirikan di atas tanah dan setiap tempat memiliki karakteristik yang berbeda, maka, konteks iklim dan geografi menjadi pedoman dalam membangun.

Bertumpu pada kenyataan iklim tropis lembap di Nusantara, manusia Nusantara membangun sebuah pernaungan untuk mewadahi kegiatan sehari-hari. Walaupun aktivitas mereka banyak dilakukan di luar, lantas bangunan menjadi tempat untuk beristirahat dan menyimpan di malam hari; sedangkan ruang perantara seperti serambi dan kolong menjadi sarana kegiatan di siang hari. Di samping itu, sabuk gempa pasifik yang melintasi bumi Nusantara menjadikan wilayah ini rawan terhadap gempa. Alih-alih menggunakan batu sebagai 
bahan untuk membangun, kayu dipilih sebagai material utama karena ketersediannya yang melimpah serta sifatnya yang lentur dan tanggap terhadap gempa. Tentu, hal ini bertolak belakang dengan arsitektur empat musim yang mendirikan bangunan sebagai perlindungan.

\subsubsection{EKSPRESI DALAM ARSITEKTUR}

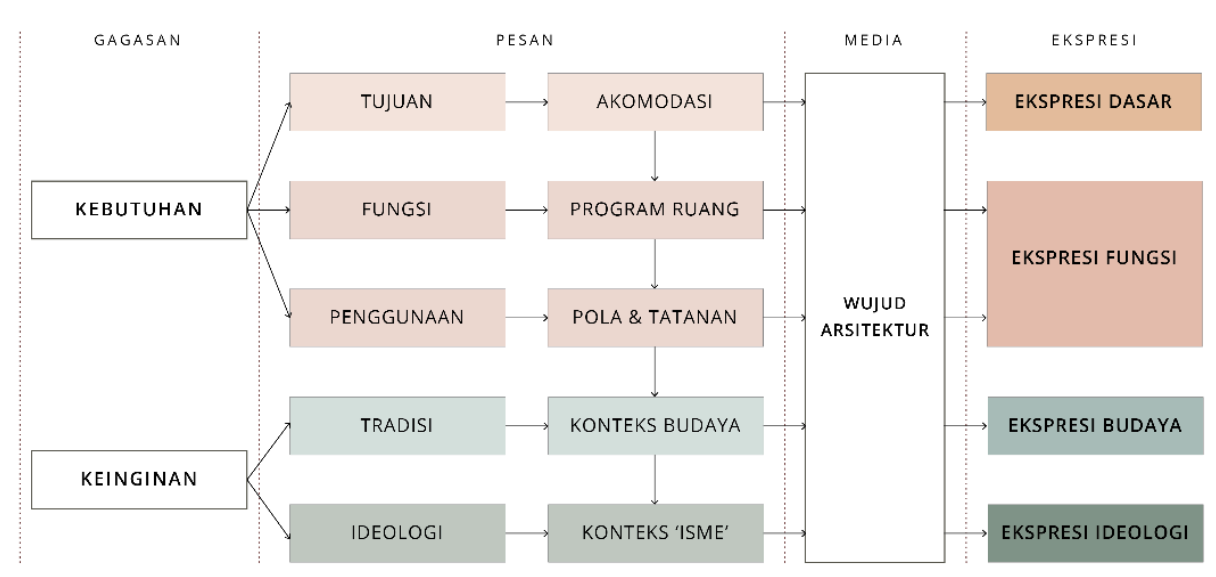

Gambar 3 Relasi antara kebutuhan dan keinginan pada ekspresi arsitektural Sumber: Bahan Ajar "Pengantar Teori Bentuk dan Makna" oleh Purnama Salura

Bahasa merupakan salah satu bentuk komunikasi verbal dan arsitektur merupakan bentuk komunikasi non verbal atau visual. Bertolak dari pemahaman tersebut, maka, objek arsitektur mengandung muatan pesan yang terwujud pada susunan elemen-elemen pembentuknya. Bani Noor Muchammad dan Ikaputra (2010) mengatakan bahwa ekspresi dalam bidang arsitektur meliputi tiga komponen, yaitu pesan, media, dan penerima. Sementara itu, Purnama Salura mengatakan bahwa, ekspresi dalam arsitektur merupakan wujud dari gagasan akan kebutuhan dan keinginan (Gambar 3). Ekspresi berlandaskan kebutuhan merupakan ekspresi dasar dalam arsitektur yang meliputi tujuan, fungsi, dan kegunaan dari bangunan. Berlainan dengan hal itu, ekspresi berlandaskan keinginan merupakan ekspresi yang mengungkapkan perihal tradisi dan ideologi yang memengaruhi arsitektur; aspek-aspek yang memperkaya arsitektur.

Berdasarkan pemaparan sebelumnya, dapat disimpulkan bahwa ekspresi dalam arsitektur ialah proses pengungkapan pesan dan makna simbolik oleh objek arsitektur yang dapat dipahami dan dibaca melalui aspek rupa maupun aspek nirupa. Dalam menentukan ekspresi pada objek arsitektur, dapat dilakukan pemerian pada tata massa, alih-bentuk geometri, struktur, material, serta komposisi fasadnya. 


\subsubsection{KONSEP PROPERTI - KOMPOSISI DALAM ARSITEKTUR}

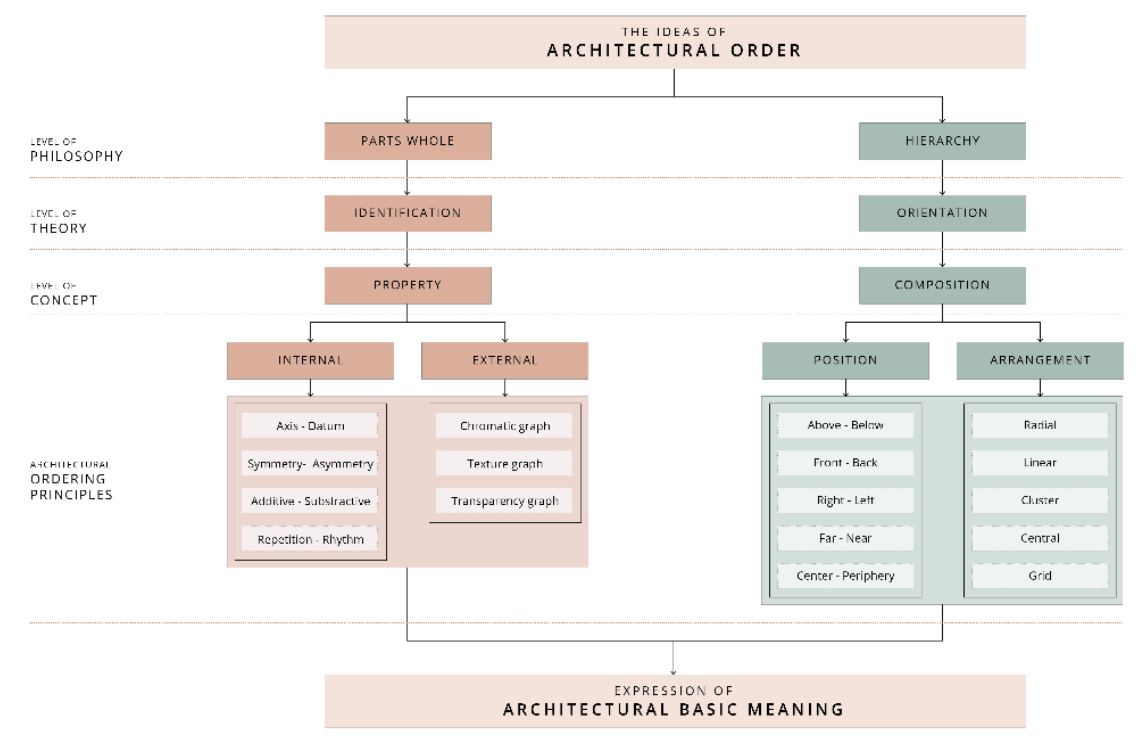

Gambar 4 Relasi antara filsafat, teori, dan konsep prinsip penataan arsitektur Sumber: Bahan ajar "Pengantar Teori Bentuk dan Makna" oleh Purnama Salura

Melalui buku Arsitektur: Bentuk, Ruang, dan Tatanan, Francis DK Ching (1979), menawarkan teori prinsip-prinsip penataan dalam arsitektur. Prinsip penataan ini terdiri atas aspek-aspek esensial dalam mencipta komposisi yang padu, yakni sumbu, simetri, hirarki, ritma, datum, dan transformasi. Beliau menjabarkan penerapan prinsip-prinsip penataan itu di dalam arsitektur saja. Akan tetapi, tidak ditemukan penjelasan yang mendalam terkait hubungan dari keenam aspek tersebut. Dalam jurnalnya, Purnama Salura (2018) mengatakan bahwa keenam aspek yang ditawarkan Ching belum memiliki dasar yang kuat. Meskipun begitu, buku ini kerap menjadi pedoman dalam mengajar.

Menurut beliau, konsep properti dan komposisi selalu hadir di dalam wujud arsitektur dan dalam proses merancang arsitektur. Keduanya saling mendukung dan hubungannya dapat dilihat; salah satu mendominasi atau keduanya seimbang. Kemudian, prinsip ini disebut sebagai prinsip penataan dalam arsitektur (Gambar 4). Konsep properti terbagi menjadi dua, yakni properti internal dan properti eksternal. Properti internal mencakup bentuk dasar fisik, seperti kepadatan, ukuran atau volume; serta prinsip sumbu-datum dan repetisi-ritme. Sedangkan properti eksternal mencakup warna, tekstur dan transparansi.

Posisi atau orientasi suatu benda terhadap benda lainnya turut memengaruhi atribut, kualitas, atau karakter fisiknya. Benda yang disusun pada posisi dan arah tertentu akan membentuk sebuah komposisi. Dalam hal ini, konsep komposisi dibedakan berdasarkan posisi, yakni atas-bawah, depan-belakang, kanan-kiri, dan jauh-dekat. Selain itu, dapat dibedakan berdasarkan susunan antar objeknya seperti memusat, linier, klaster, atau grid. 


\subsubsection{KERANGKA KONSEPTUAL}

Dalam merumuskan matriks pembentuk ekspresi kenusantaraan, studi pustaka terkait properti dan komposisi arsitektur nusantara ditabulasikan dalam tiga lingkup menurut teori anatomi arsitektur (Salura, 2018). Dengan ini, ekspresi kenusantaraan dapat diamati melalui lingkup tapak, lingkup bangunan, dan lingkup struktur. Lebih lanjut, hasil-hasil temuan pada kajian pustaka dirangkum dalam tabel berikut:

Tabel 1 Matriks pembentuk Ekspresi Kenusantaraan

\begin{tabular}{|c|c|c|c|c|}
\hline & \multirow{2}{*}{ Elemen } & \multicolumn{2}{|c|}{ Properti } & \multirow{2}{*}{ Komposisi } \\
\hline & & Bagian & Karakteristik & \\
\hline \multirow{4}{*}{ 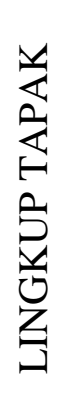 } & \multirow{4}{*}{ Atribut tapak } & $\begin{array}{l}\text { Massa } \\
\text { bangunan }\end{array}$ & Modular & $\begin{array}{l}\text { Linier atau } \\
\text { berkelompok }\end{array}$ \\
\hline & & \multirow{2}{*}{ Halaman } & \multirow{2}{*}{$\begin{array}{l}\text { Elemen lunak } \\
\text { (Softscape) }\end{array}$} & $\begin{array}{l}\text { Posisi halaman } \\
\text { mengelilingi bangunan }\end{array}$ \\
\hline & & & & Hierarkis/dominan \\
\hline & & Pencapaian & Frontal & Linier \\
\hline \multirow{6}{*}{ 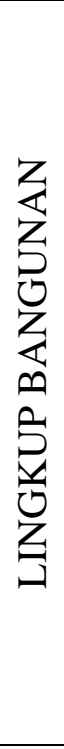 } & \multirow[t]{2}{*}{ Pelingkup atas } & \multirow[t]{2}{*}{ Atap } & $\begin{array}{l}\text { Bangun prisma, } \\
\text { limas, atau } \\
\text { kerucut }\end{array}$ & \multirow[t]{2}{*}{ Hierarkis/dominan } \\
\hline & & & $\begin{array}{l}\text { Simetri - } \\
\text { Asimetri }\end{array}$ & \\
\hline & \multirow{3}{*}{ Pelingkup samping } & \multirow{3}{*}{ Dinding } & $\begin{array}{l}\text { Bidang } \\
\text { bercelah }\end{array}$ & \multirow{3}{*}{$\begin{array}{l}\text { Grid; Menghubungkan } \\
\text { ruang dengan } \\
\text { lingkungan secara } \\
\text { tidak langsung }\end{array}$} \\
\hline & & & $\begin{array}{l}\text { Terdapat pintu } \\
\text { dan jendela }\end{array}$ & \\
\hline & & & $\begin{array}{l}\text { Terdapat } \\
\text { ornamen }\end{array}$ & \\
\hline & Pelingkup bawah & Lantai & $\begin{array}{l}\text { Bidang, } \\
\text { modular }\end{array}$ & $\begin{array}{l}\text { Memiliki derajat } \\
\text { elevasi berbeda dengan } \\
\text { muka tanah }\end{array}$ \\
\hline \multirow{5}{*}{ 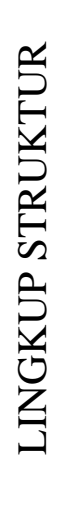 } & Struktur Atas & Atap & Bidang & - \\
\hline & \multirow{3}{*}{ Struktur Tengah } & \multirow{2}{*}{ Kolom } & Repetitif & \multirow{3}{*}{$\begin{array}{l}\text { Struktur diletakkan } \\
\text { mengelilingi } \\
\text { bangunan; membentuk } \\
\text { selasar, teras, atau } \\
\text { beranda }\end{array}$} \\
\hline & & & Menerus & \\
\hline & & Balok & Tumpuan sendi & \\
\hline & Struktur Bawah & Landasan & Tumpuan roll & $\begin{array}{l}\text { Posisi struktur berada } \\
\text { di atas tanah }\end{array}$ \\
\hline
\end{tabular}




\section{METODE PENELITIAN}

Metode yang digunakan dalam penelitian ini bersifat kualitatif dengan pendekatan deskriptif-analitis. Hasil penelitian ini diharapkan dapat memperkaya wawasan praktisi dalam mencipta lingkungan binaan yang mengkini berlandaskan pengetahuan arsitektur Nusantara, serta melengkapi penelitian arsitektur Nusantara di luar ambang teori.

\section{ANALISIS \\ 4.1 ARSITEKTUR BALAI ADAT SESAT AGUNG}

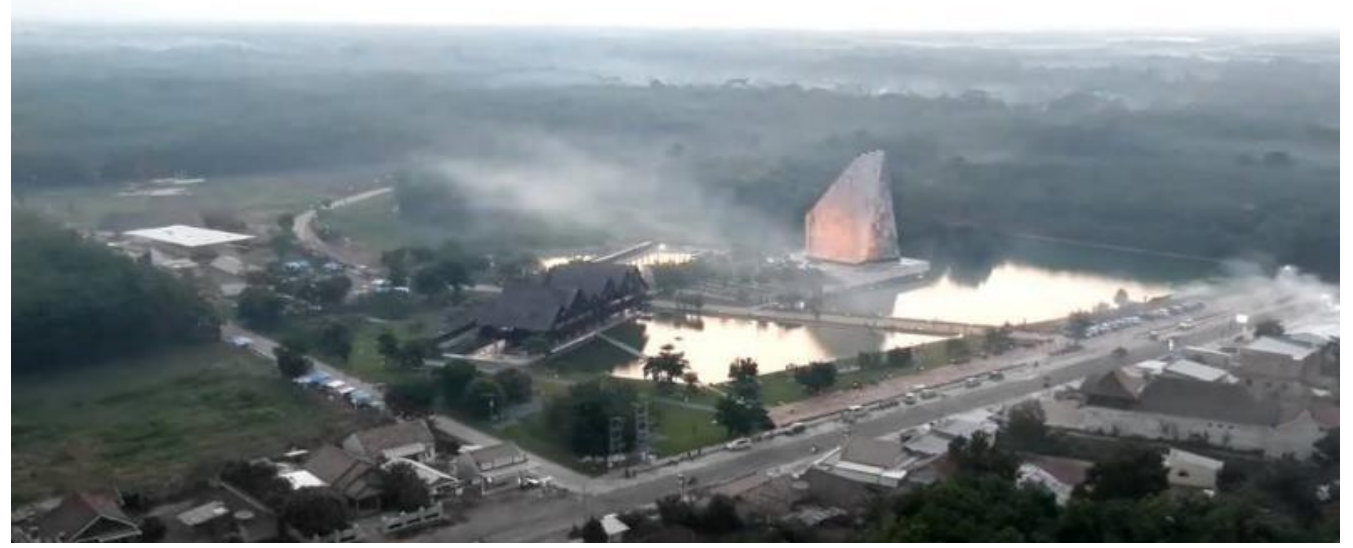

Gambar 5 Potret udara arsitektur Balai Adat Sesat Agung

Sumber: Situs resmi Pemkab Tubaba (Diakses pada November 2020)

Berdiri di atas lahan kosong yang semula berupa rawa-rawa dan perkebunan karet, Sesat Agung telah menggoreskan warna arsitektur yang baru di Tubaba. Sesat Agung merupakan balai adat bagi masyarakat Tubaba. Selain berfungsi sebagai tempat pertemuan, ragam perhelatan keagamaan dan kesenian telah dilangsungkan di Sesat Agung. Balai ini berbatasan langsung dengan Masjid As-sabur dan Jalan Panaragan Jaya. Sesat Agung memiliki luas tanah $16.464 \mathrm{~m}^{2}$ dengan luas bangunan utama $1.000 \mathrm{~m}^{2}$.

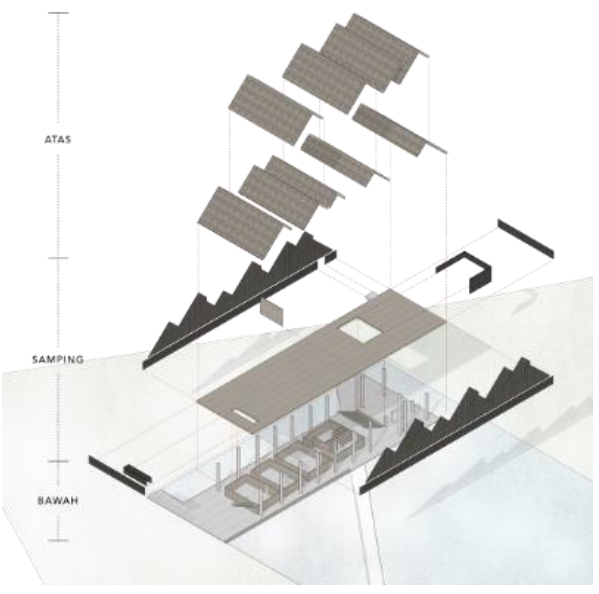

Gambar 6 Isometri lingkup bangunan

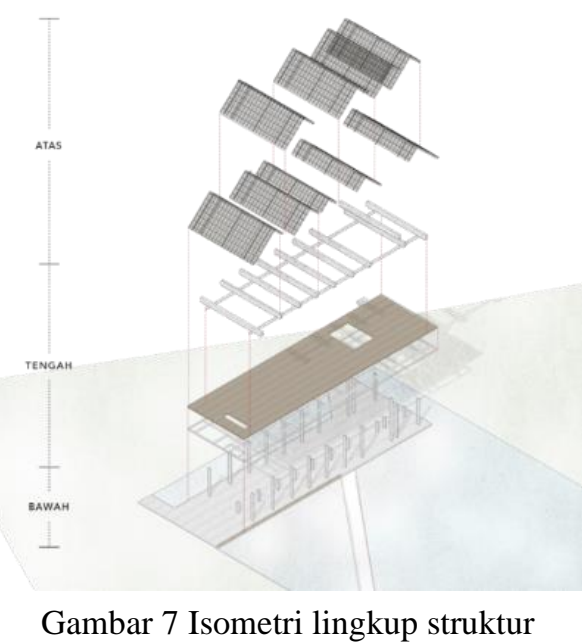

Atap Sesat Agung memiliki dua tingkat susunan atap pelana (Gambar 6). Susunan pertama terdiri dari lima atap yang melambangkan lima pulau besar di Indonesia. Pada susunan kedua, susunan empat buah atap itu mewakili empat marga besar di Tubaba, yakni puyang umpu, puyang bulan, puyang aji, dan puyang tegamoan. Setiap susunan ini memiliki titik putus dan sambung seperti rangkaian aksara Lampung; saling merangkul satu sama lain. Hal ini 
sejalan dengan sejarah Tubaba sebagai tempat persinggahan bagi para transmigran. Di ruang dalam, material plafon kayu ini diukir bertuliskan falsafah hidup masyarakat Tubaba.

Elemen pelingkup samping Sesat Agung terdiri dari dinding, pintu, dan jendela. Ruang pengelola di lantai dasar menggunakan panel kayu sebagai pembatas zona publik dan privat. Sementara itu, dinding lantai satu menggunakan kisi-kisi kayu dengan rentang yang cukup rapat. Celah antarkisi mengizinkan angin untuk masuk ke seluk beluk ruang. Alas bangunan Sesat Agung dibedakan berdasarkan elevasi dan material. Elevasi lantai dari sisi terluar bangunan diturunkan sebesar 1 meter, kemudian dinaikkan ke elevasi semula. Material lantai pada lantai dasar merupakan beton, dan lantai atas menggunakan material papan kayu.

Struktur atap bangunan ini menggunakan sistem rangka dengan material baja (Gambar 7). Struktur ini ditopang oleh balok-balok menerus dengan ukuran 50 x $100 \mathrm{~cm}$. Strategi pemilihan material dan sistem struktur sejalan dengan kebutuhan fungsi Sesat Agung sebagai balai pertemuan. Bangunan ini menggunakan kolom beton bertulang dengan ukuran 30 x 50 $\mathrm{cm}$ yang disusun dengan pola grid. Sistem konstruksi bangunan ini menggunakan sistem rangka kaku beton bertulang.

\subsection{EKSPRESI KENUSANTARAAN PADA BALAI ADAT SESAT AGUNG}

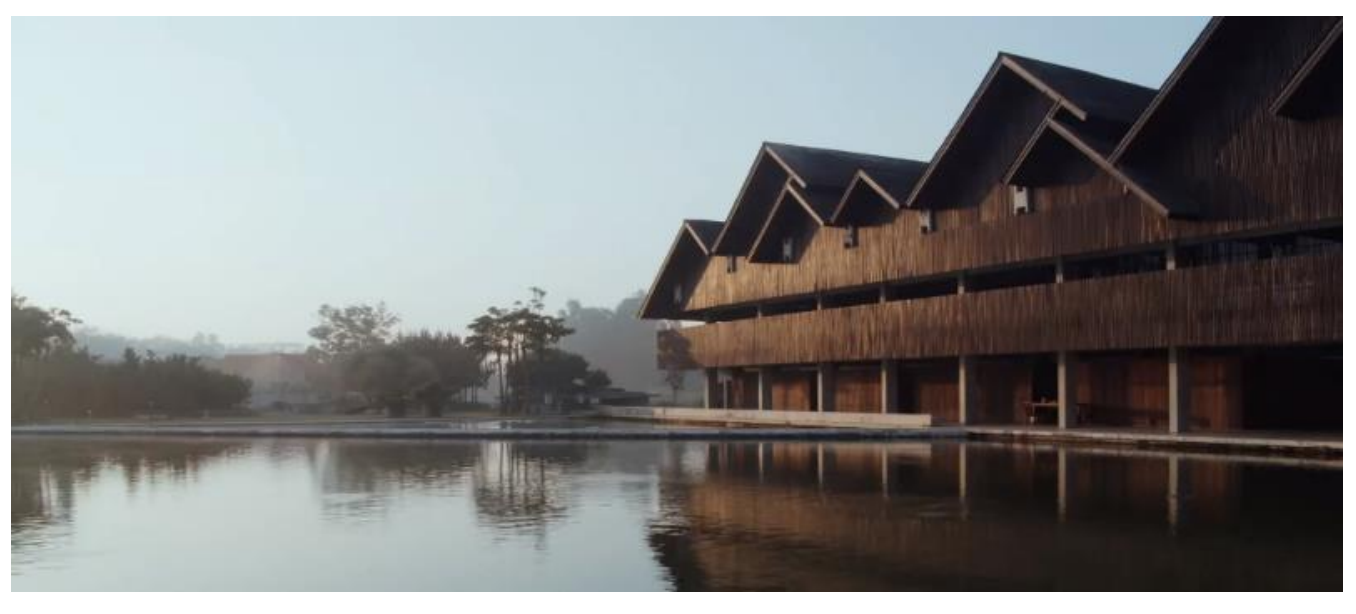

Gambar 8 Eksterior arsitektur Sesat Agung

Sumber: Situs resmi Pemkab Tubaba (Diakses pada November 2020)

Di usianya yang belia, Kabupaten Tulang Bawang Barat semakin dikenal hingga mancanegara. Daerah yang dijuluki Bumi Ragem Sai Mangi Mawai lahir pada tahun 2008 bersama dua kabupaten lainnya. Atas perintah Bupati Umar Ahmad, agenda pembangunan Tubaba tidak terbatas pada lingkup ekonomi dan infrastruktur saja, namun turut membangun sumber daya manusia melalui kesenian dan kebudayaan. Pemerintah Kabupaten Tulang Bawang Barat menggandeng arsitek dan pegiat seni untuk membangun masa depan Tubaba dengan identitas baru dari masa lalu.

Dari sembilan rangkaian pembangunan di Tubaba, Balai Adat Sesat Agung merupakan salah satu bangunan kontemporer yang memelopori arah baru pembangunan Tubaba. Ekspresi arsitektur Sesat Agung yang kental akan semangat kebaruan dianggap berhasil mereka ulang jejak sejarah dan budaya dalam membangun asa di Tubaba. Sehubungan dengan itu, pencermatan atas atribut arsitektur Sesat Agung dilakukan dalam tiga lingkup: tapak, bangunan, dan struktur. Pada lingkup tapak, atribut yang akan dikaji antara lain massa bangunan, halaman, serta pencapaian. Seusai mencermati atribut tapak, pencermatan dilanjutkan dengan melakukan pemerian pada lingkup bangunan yang terdiri dari tiga elemen pelingkup: atas, samping, dan bawah. Kemudian, hubungan antar-elemen tersebut dicermati lebih lanjut pada lingkup struktur. Setiap atribut dari ketiga lingkup itu dikaji berdasarkan 
konteks fungsi, iklim, dan geografi setempat. Lalu, arsitektur Sesat Agung disandingkan dengan arsitektur Lampung untuk menemukenali ekspresi kenusantaraan pada arsitektur Sesat Agung.

\subsubsection{LINGKUP TAPAK}
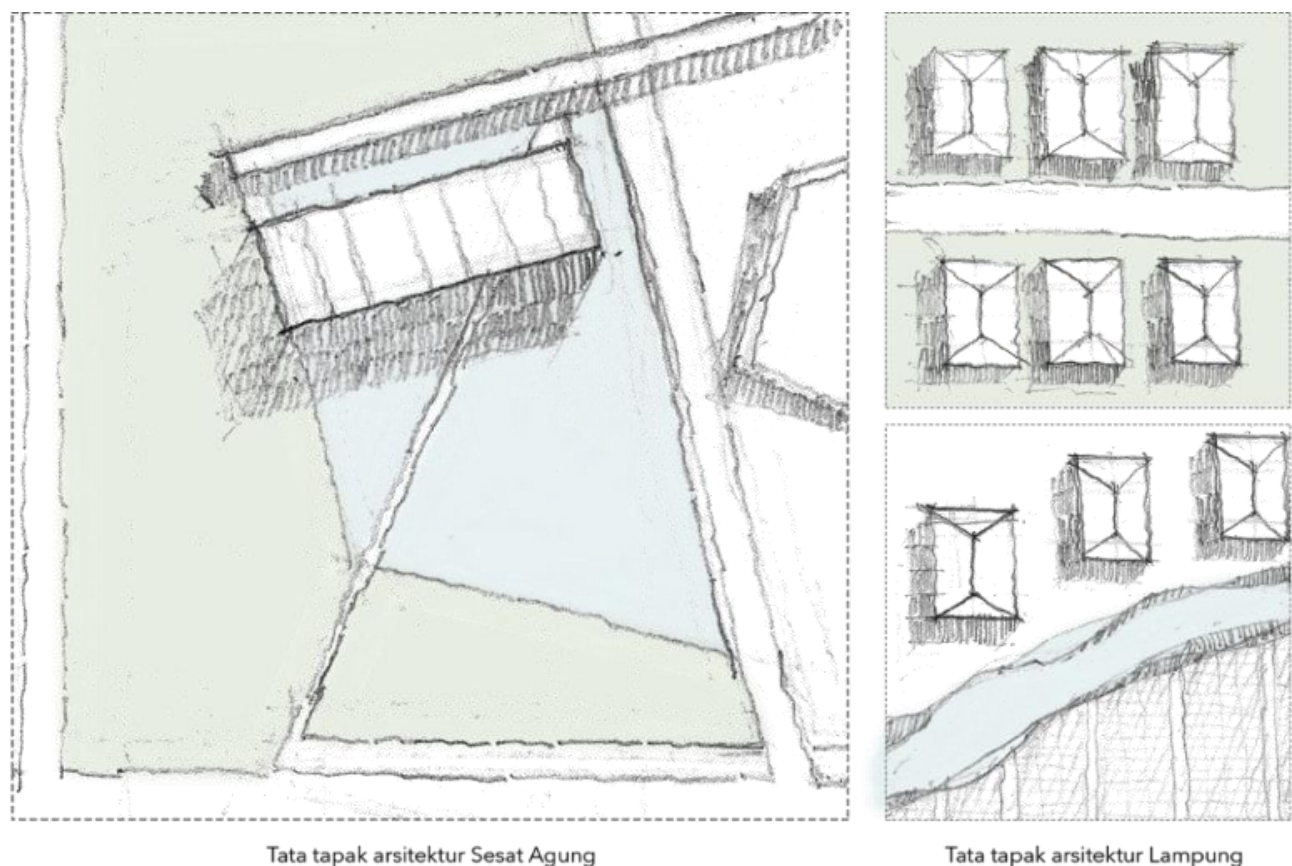

Gambar 9 Persandingan pada lingkup tapak

Kompleks "Islamic Center" terletak di jantung ibukota Tubaba yang terdiri dari Masjid As-Sabur, Balai Adat Sesat Agung, serta hotel. Sebagai satu kesatuan dengan masjid di sebelahnya, Sesat Agung memiliki arah hadap yang menyimpang dari kawanan massa lainnya. Dalam menata tapak, arsitektur Sesat Agung berpedoman pada dua sumbu untuk menciptakan dualitas orientasi. Kendati demikian, ruang-ruang di lantai dasar diatur - dalam komposisi linier - secara tegak lurus terhadap poros jalan (Gambar 9). Tatanan seperti ini kerap ditemukan pada tata tapak arsitektur Lampung yang linier terhadap jalan dan sungai. Poros-poros diagonal itu tidak sekedar sikap bangunan terhadap masjid, tetapi juga untuk menghemat jarak tempuh pengunjung menuju akses utama yang terletak 110 meter dari Jalan Panaragan Jaya. Suasana permukiman tepi sungai - yang telah lama ditinggalkan - tersaji dalam bentuk perjalanan menurun dan mendaki bersama keindahan yang dipantulkan oleh kolam di kedua sisinya. Di sini, kolam tidak sekedar merekayasa iklim mikro saja, tetapi juga menanggulangi krisis air bersih di musim kemarau dan banjir di musim hujan.

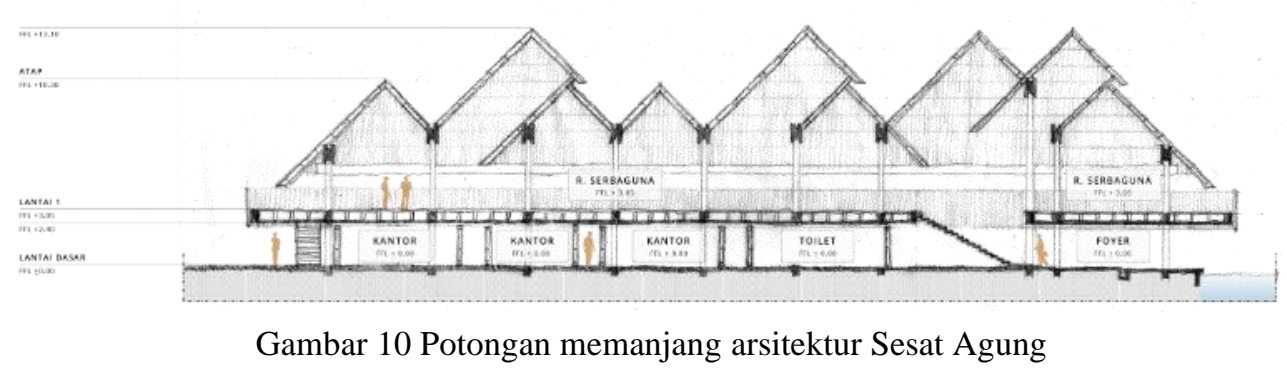


Komposisi spasial Balai Adat Sesat Agung terdiri dari fungsi konvensi dan administrasi. Ruang konvensi sebagai fungsi utama bangunan berada di lantai satu, sedangkan ruang administrasi di lantai dasar disusun secara modular membentuk tatanan yang linier. Penyelesaian ruang dan sirkulasi pada lantai bawah terimplementasi dengan baik untuk memecah arus pengunjung dari kedua arah (Gambar 10). Tangga berukuran 7 x 6 meter ini diletakkan di sisi timur bangunan menghadap masjid di seberangnya. Ukuran tangga yang dominan menunjukkan pangkatnya sebagai akses utama bangunan. Akan tetapi, letak tangga utama ini berimbas pada tata ruang di lantai satu yang terpenggal menjadi bagian-bagian yang tidak proporsional (Gambar 10). Pembagian ruang yang tidak proporsional ini berpotensi memecah konsentrasi ruang serbaguna yang bersifat menerus. Berlainan dengan itu, tangga sekunder yang diletakkan di tepi bangunan tidak mengganggu dinamika interaksi antarpengunjung di dalam ruang.

\subsubsection{LINGKUP BANGUNAN}

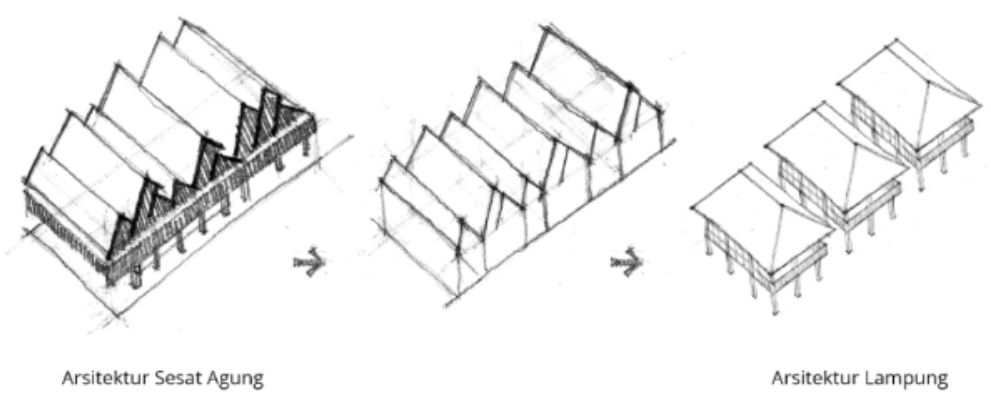

Gambar 11 Persandingan pada lingkup bangunan

Dalam kesederhanaan, Balai Adat Sesat Agung berbaring telentang di atas air. Selain proporsinya yang rendah dan memanjang, ada sabuk panjang yang membagi bangunan menjadi tiga bagian, sekaligus mengikat komposisi atap yang tak teratur. Meskipun begitu, susunan atap yang berjenjang itu tetap mendominasi tampilan-rupa arsitektur Sesat Agung.

Jika dicermati secara saksama, titik putus-sambung antarbidang atap itu membentuk pola yang teratur (Gambar 11). Apabila titik itu diproyeksikan tegak lurus terhadap alas, maka, segmen-segmen garis tersebut memenggal bangunan menjadi tiga bagian dalam dua varian ukuran. Secara kasat mata, rentang pada susunan ini memiliki pola yang serupa dengan barisan tiga rumah Lampung. Oleh karena kegiatan konvensi yang diakomodasi oleh Sesat Agung menuntut ruang dengan bentang yang besar, maka, ketiga rumah Lampung itu dihubungkan oleh tiga atap kecil. 
Atap Sesat Agung

Komposisi Atap

Atap Kecil

Atap Rumah Lampung

Barisan Rumah Lampung
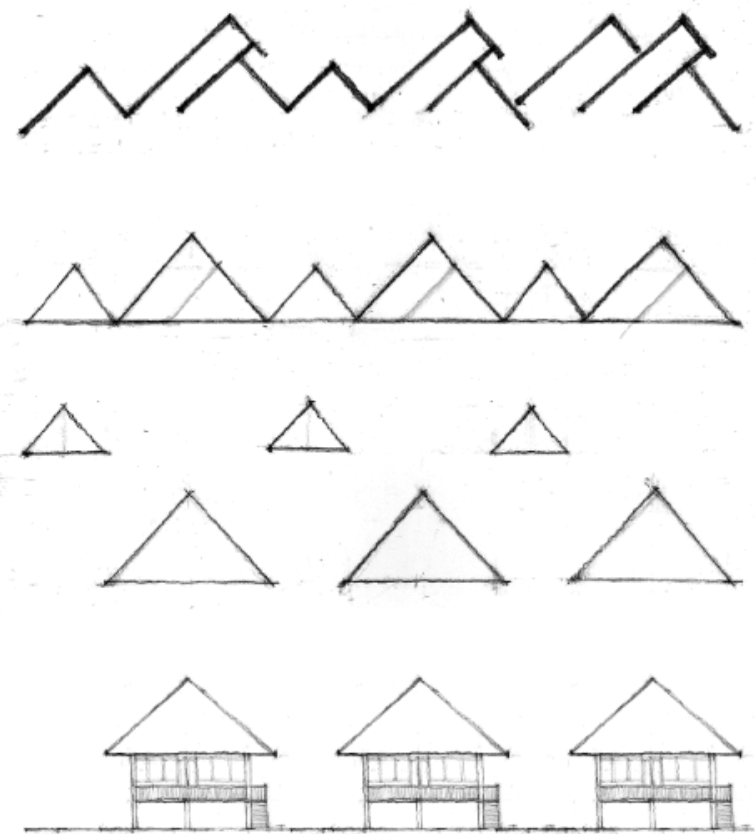

Gambar 12 Persandingan pada elemen pelingkup atas

Lantaran syarat teknis dan fungsional, atap digubah secara asimetris untuk menangkis panas dan menepis hujan (Gambar 12). Pada tingkat pertama, sepenggal garis tepi segitiga itu digeser ke dalam sejauh sepertiga dari panjang sisinya. Kemudian, sudut kemiringan segitiga diatur untuk mencegah masuknya air hujan ke dalam bangunan. Lalu, susunan atap ini ditunjang oleh balok-balok struktur di bawahnya. Terlepas dari syarat dan ketentuan teknis yang membagi atap secara asimetris, koreografi antarbidang miring membentuk komposisi yang dinamis.
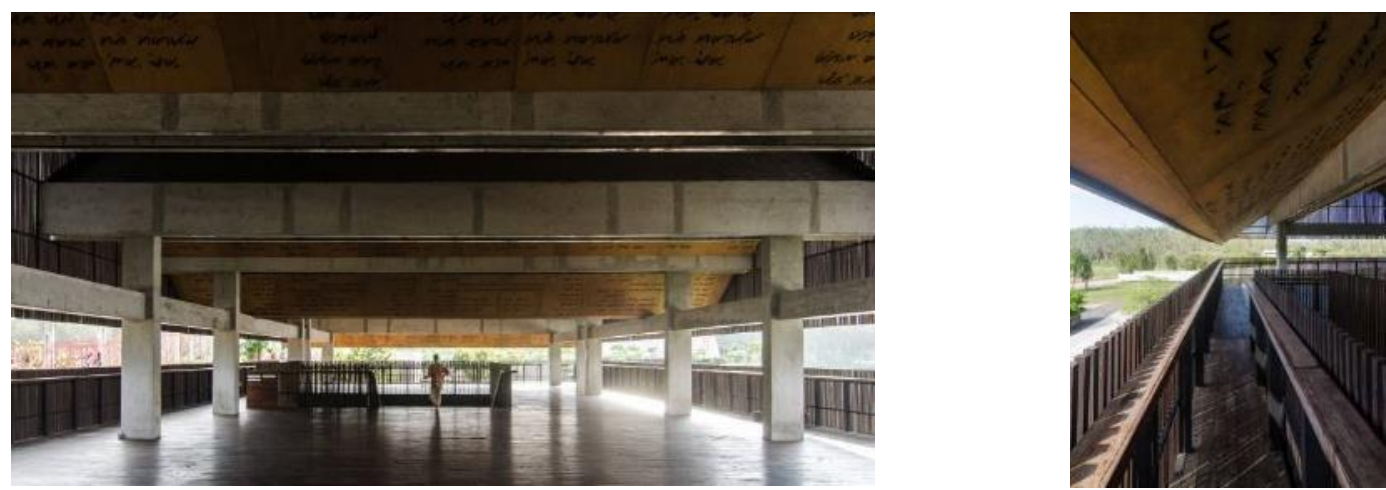

Gambar 13 Ruang dalam arsitektur Sesat Agung Sumber: Studio andramatin

Biasanya, struktur rangka atap rumah Lampung ditampilkan secara jujur dan sederhana. Akan tetapi, kegiatan konvensi yang kerap dilakukan di dalam ruangan membuka kesempatan bagi ruang dalam Sesat Agung untuk ditangani secara estetis. Sehubungan dengan ini, langitlangit yang menggantung di bawah rangka atap itu dihiasi dengan ukiran aksara Lampung (Gambar 13). 

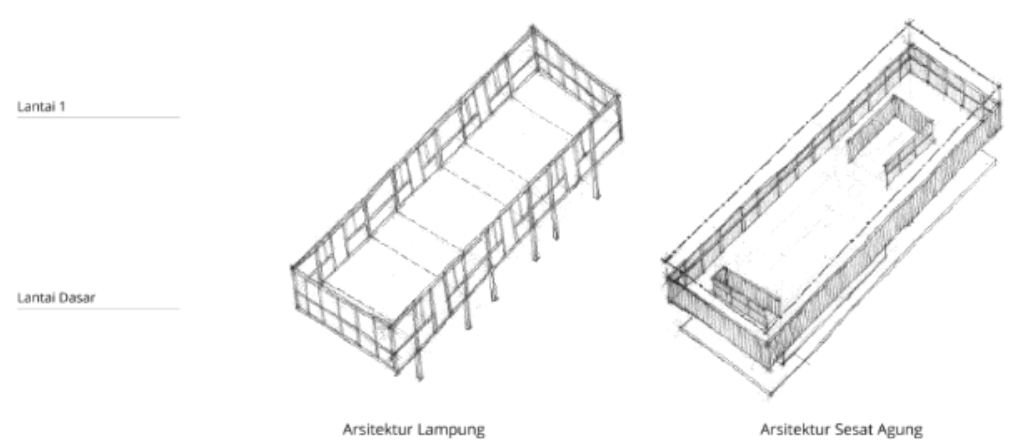

Gambar 14 Persandingan pada elemen pelingkup samping

Susunan bilah kayu yang menjulang hingga ambang atap berfungsi sebagai dinding dan lubang angin secara simultan. Rangka-rangka ini sengaja disembunyikan guna merekayasa tampilan yang rapi dan apik. Tentu, hal ini bertolak belakang dengan dinding arsitektur Lampung yang disusun selaras dengan modul-modul struktur; membentuk rangkaian grid (Gambar 14). Meskipun pintu, jendela, dan ragam hias tidak ditemukan dalam komposisi selubung arsitektur Sesat Agung, namun, kisi-kisi kayu sebagai pelingkup dan lubang angin merupakan implementasi dari ragam hias arsitektur modern yang menghendaki kejujuran dan kesederhanaan.

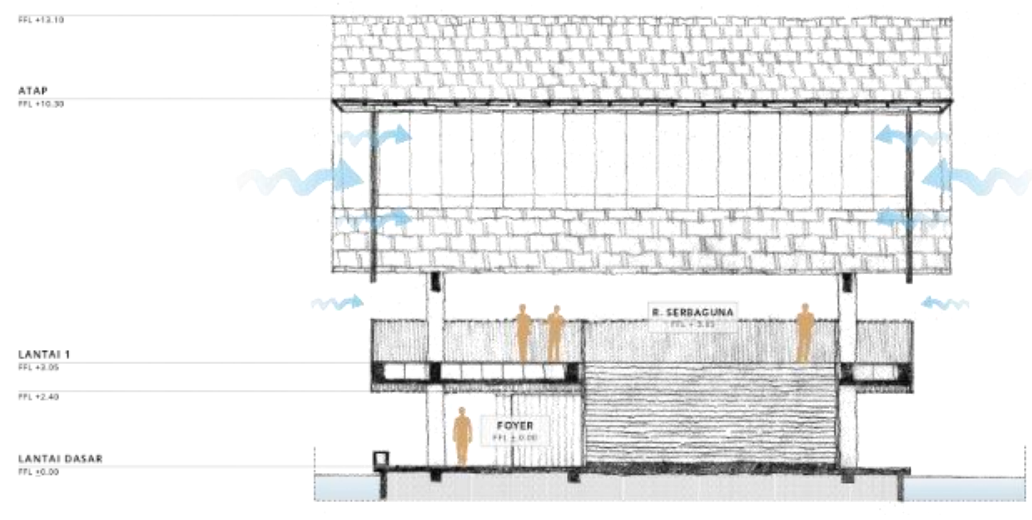

Gambar 15 Potongan melintang arsitektur Sesat Agung

Lazimnya, ruang serbaguna dilingkupi oleh dinding yang masif. Dinding ini berperan sebagai pembatas antara ruang luar dan ruang dalam, sehingga suara kegiatan di dalam ruangan tidak mengganggu lingkungan sekitarnya - begitupula sebaliknya. Selain itu, pintu tidak hanya sebagai penghubung antara ruang serbaguna dengan ruang-ruang lainnya tetapi juga mengatur dinamika aktivitas pengunjung. Dengan kata lain, susunan bilah kayu yang melingkupi ruang serbaguna bukan solusi jitu dalam pemecahan masalah kebutuhan dan kegiatan yang diakomodasi oleh bangunan (Gambar 15). Meskipun bilah-bilah kayu itu menghasilkan bayangan yang apik dan artistik, namun tidak mampu menyikapi hal-hal mendasar yang berkaitan erat dengan kualitas spasial. 


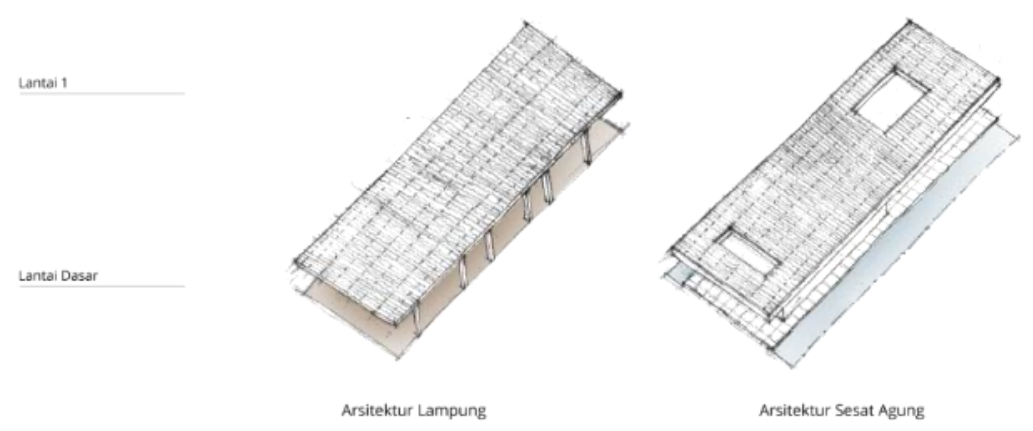

Gambar 16 Persandingan pada elemen pelingkup bawah

Pada lantai dasar, kesinambungan antara ruang luar dan ruang dalam terimplementasi dengan baik. Sama halnya dengan arsitektur Lampung, lantai dasar pada arsitektur Sesat Agung merupakan ekstensi dari lingkungan sekitarnya (Gambar 16). Begitupula dengan penutup alas pada lantai satu yang ditunjang oleh konstruksi lantai kayu. Lain halnya dengan arsitektur Lampung yang menampilkan sambungan secara jujur dan sederhana, konstruksi lantai ini bersemayam di antara pelat dan balok beton monolit.

\subsubsection{LINGKUP STRUKTUR}

\begin{tabular}{|l|l|l|l|l|}
\hline $\begin{array}{l}\text { Pertemuan atap dan } \\
\text { dinding }\end{array}$ & & & \\
\hline $\begin{array}{l}\text { Pertemuan dinding dan } \\
\text { lantai }\end{array}$ & & & \\
\hline $\begin{array}{l}\text { Pertemuan lantai dan } \\
\text { pedestal }\end{array}$ & & & \\
\hline
\end{tabular}

Gambar 17 Persandingan pada lingkup struktur

Sistem struktur bentang lebar yang digunakan oleh arsitektur Sesat Agung ialah perpaduan sistem rangka dan bidang. Rangkaian kolom dan balok beton yang saling mengikat itu membentuk modul struktur 6 x 12 meter. Berlainan dengan itu, struktur atap bangunan ini menggunakan rangka baja ringan yang tersusun rapat guna merekayasa mekanisme penyaluran 
beban secara multi arah. Dalam upaya meringankan beban bangunan, rangka dinding sengaja dipisahkan dari struktur utama. Dinding bangunan ini menggunakan papan kayu ulin yang bersandar pada rangka baja ringan. Tentu, teknik ini berbeda dengan konstruksi dinding arsitektur Lampung yang disisipkan di antara struktur utama bangunan.

Rekayasa penyaluran beban pada bangunan ini melahirkan detail-detail konstruksi yang baru dan segar (Gambar 17). Misalnya, rangka dinding yang menggantung di bawah rangka atap; juga rangka yang dijangkarkan ke pelat dan alas. Begitupun dengan pedestal yang tertanam di dalam tanah sebagai implikasi dari bentang yang cukup besar. Kendati material dan detail konstruksi yang digunakan berbeda, namun pertemuan antara atap, dinding, dan pedestal menganut sistem hubungan yang sama dengan arsitektur Lampung, yakni sistem jepit.

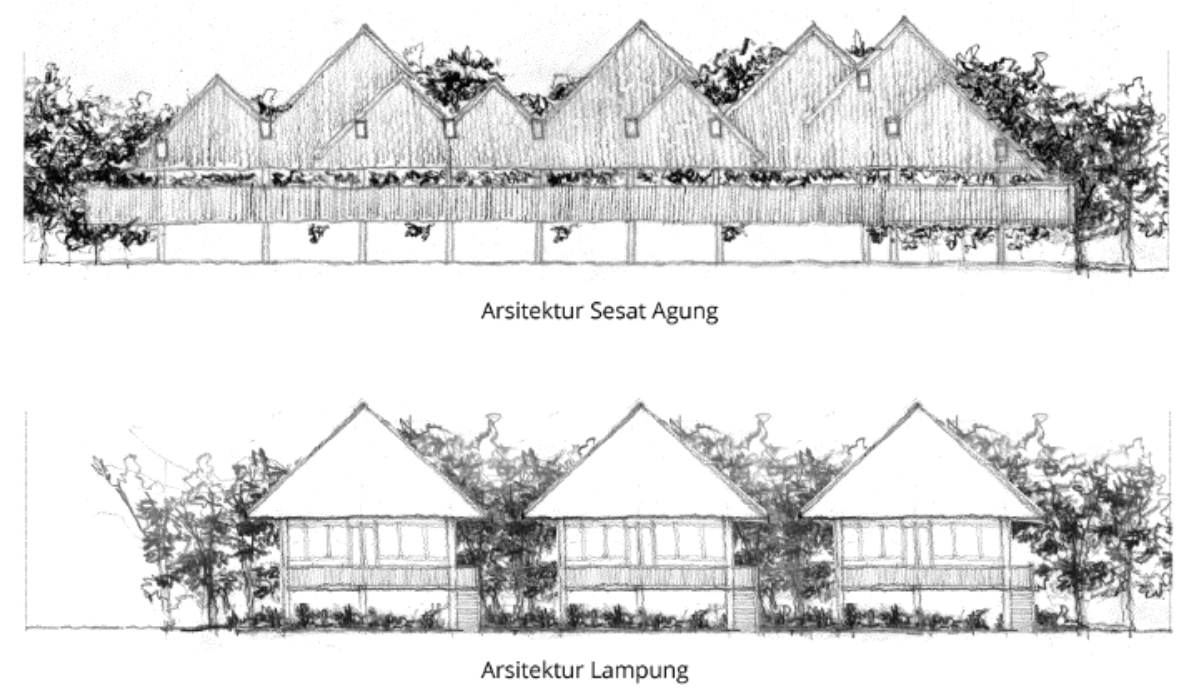

Gambar 18 Persandingan arsitektur Sesat Agung dan arsitektur Lampung

Secara keseluruhan, arsitektur Sesat Agung mampu memproyeksikan estetika arsitektur Nusantara. Proporsi bangunan berusaha untuk dipertahankan dengan suguhan bentuk atap yang baru. Begitupula dengan pencapaian menuju bangunan yang melibatkan pergerakan manusia. Walaupun karakteristik dan komposisi antara arsitektur Sesat Agung dan arsitektur Lampung berbeda, gubahan geometri yang dilakukan oleh arsitek berdasarkan konteks dan sejarah telah mencetak potret arsitektur baru di Tubaba.

Di balik tampilannya yang memikat, bangunan ini menyimpan sejumlah masalah teknis dan fungsional. Misalnya, kisi-kisi kayu yang melingkupi ruang serbaguna tidak hanya berfungsi sebagai lubang udara, tetapi juga sebagai celah masuknya air hujan ke dalam bangunan. Di samping itu, suara yang dihasilkan di dalam bangunan akan menimbulkan kebisingan terhadap lingkungan sekitarnya. Jadi, terlepas dari bentuk dan estetika yang disandangnya, satu hal yang lepas dari arsitektur Sesat Agung ialah kualitas kenyamanan manusia di dalamnya.

Merujuk pada matriks pembentuk ekspresi kenusantaraan yang telah disusun sebelumnya, hasil analisis ditabulasikan dalam tiga lingkup: tapak, bangunan, dan struktur. Setiap aspek dievaluasi lebih lanjut untuk mencermati kesinambungannya dengan arsitektur Lampung. Dalam konteks ini, transformasi merupakan teknik menggubah bentuk geometri dari perbendaharaan arsitektur klasik Nusantara - dengan cara menambah, mengurangi, ataupun menyusun ulang bentuk-bentuk tersebut. Sebaliknya, pengayaan ialah alih-bentuk geometri baru yang memperkaya kosakata arsitektur Nusantara. Lebih lanjut, persandingan antara arsitektur Sesat Agung dengan arsitektur Lampung tersaji pada tabel di bawah ini. 
Tabel 2 Persandingan dalam lingkup tapak

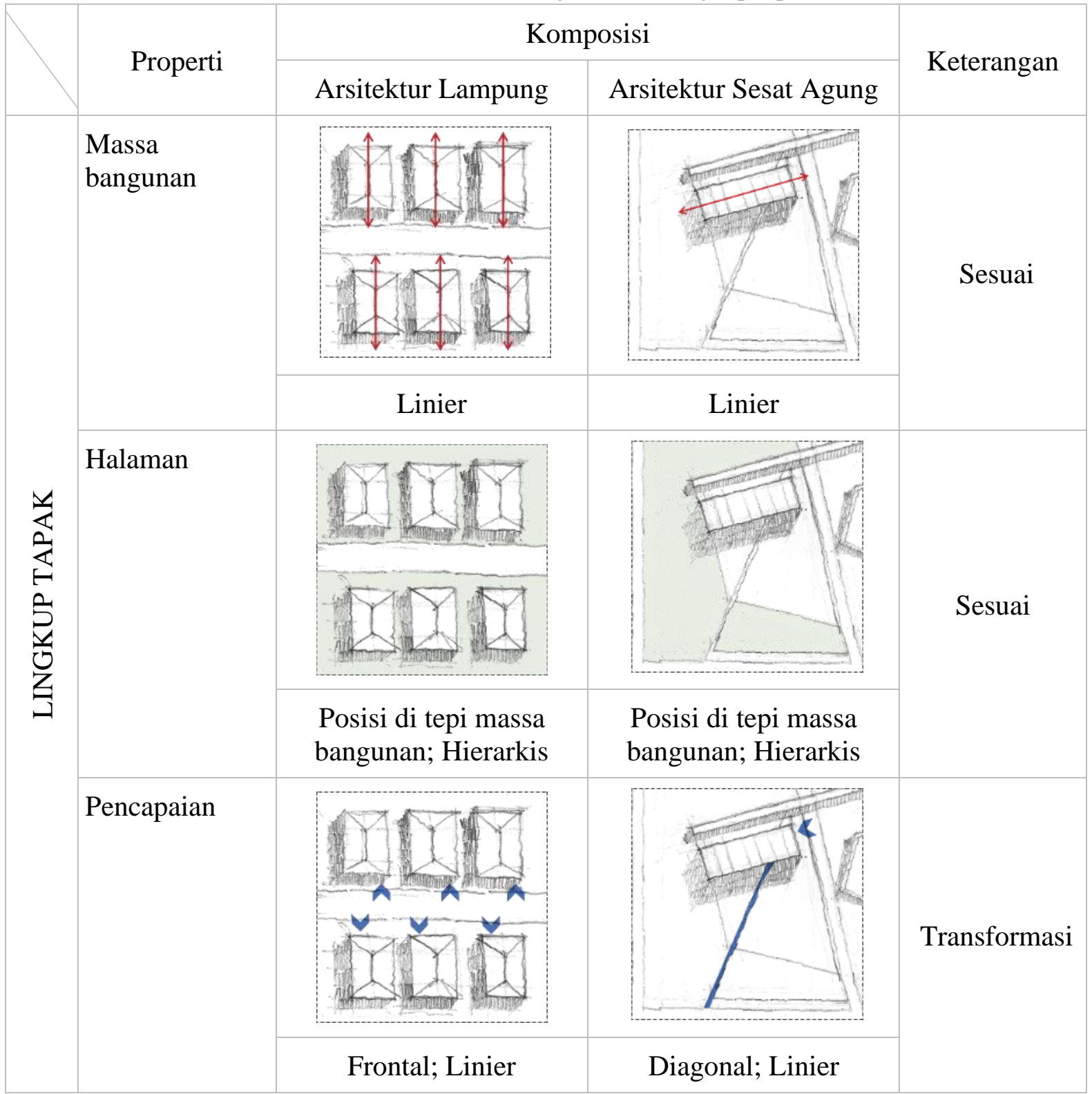


Tabel 3 Persandingan dalam lingkup bangunan

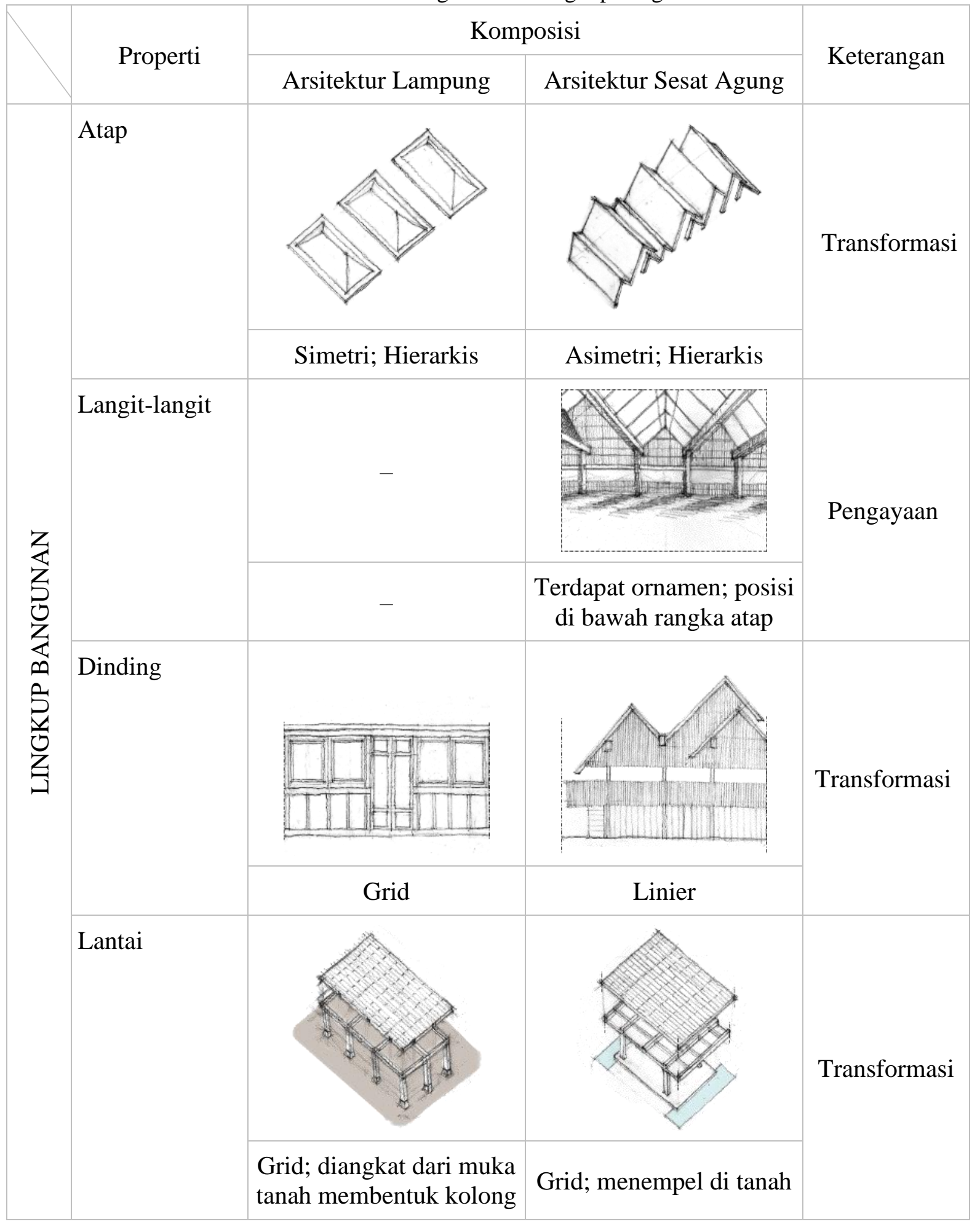


Tabel 4 Persandingan dalam lingkup struktur

\begin{tabular}{|c|c|c|c|c|}
\hline & \multirow{2}{*}{ Properti } & \multicolumn{2}{|c|}{ Komposisi } & \multirow{2}{*}{ Keterangan } \\
\hline & & Arsitektur Lampung & Arsitektur Sesat Agung & \\
\hline \multirow{6}{*}{ 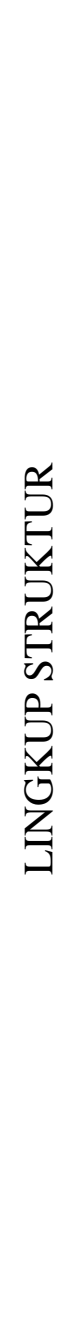 } & \multirow{4}{*}{$\begin{array}{l}\text { Pertemuan } \\
\text { dinding dan } \\
\text { lantai }\end{array}$} & & 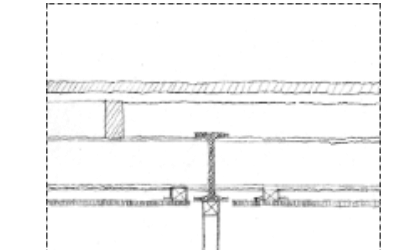 & \multirow[t]{2}{*}{ Pengayaan } \\
\hline & & $\begin{array}{c}\text { Di belakang rangka } \\
\text { bangunan }\end{array}$ & Di bawah rangka atap & \\
\hline & & II & 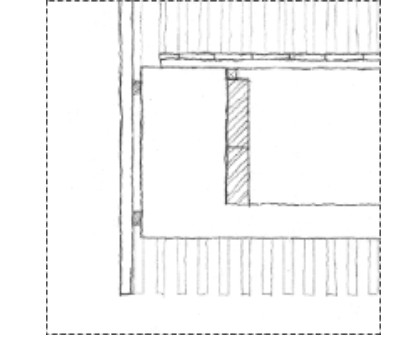 & \multirow[t]{2}{*}{ Pengayaan } \\
\hline & & Di atas struktur lantai & Di tepi struktur lantai & \\
\hline & \multirow[t]{2}{*}{$\begin{array}{l}\text { Pertemuan } \\
\text { lantai dan } \\
\text { pedestal }\end{array}$} & 正 & & \multirow{2}{*}{ Pengayaan } \\
\hline & & Di atas tanah & Di bawah tanah & \\
\hline
\end{tabular}

\section{KESIMPULAN}

Dari segala penjuru, arsitektur klasik Nusantara secara empiris telah teruji ketangguhannya dalam menyikapi kondisi alam yang tak menentu. Begitupula dengan kemampuannya dalam menaungi kegiatan sehari-hari manusia Nusantara. Tentu, arsitektur ini lahir di lingkungan dengan konteks sosial budaya yang terpaut oleh waktu. Dan karenanya, bentuk-bentuk itu memiliki kesempatan untuk berkembang seiring dengan kebutuhan masanya. Kepiawaian arsitek dalam membaca konteks menjadi peletak dasar dalam mencipta lingkungan binaan yang mengkini.

Dalam perjalanannya, Tulang Bawang Barat - yang kemudian disingkat Tubaba - telah menjadi tempat persinggahan bagi pendatang dari pelbagai daerah. Sejalan dengan pembangunan infrastruktur darat, permukiman tepi sungai bermigrasi ke tepi jalan raya. Perkembangan titik ekonomi yang sporadik berimbas pada pengelolaan lahan yang tidak merata. Atas perintah Bupati Umar Ahmad, ladang-ladang eks-proyek transmigrasi yang luas dan sepi lekas diisi dengan arsitektur sebagai roda penggerak ekonomi dan peradaban di 
Tubaba. Berkat tampilannya yang memikat, Balai Adat Sesat Agung telah membawa Tubaba mencapai satu titik dari garis panjang menuju hari depan.

Selaras dengan terobosan yang digenggamnya, arsitektur Sesat Agung berhasil mencetak identitas arsitektur baru di Tubaba. Adu manis antara barisan bilah kayu dan bidang atap itu membentuk siluet yang artistik dan trendi. Namun di balik tampilannya yang memikat, bangunan ini menyimpan sejumlah masalah teknis dan fungsional. Agaknya, iklim dan syarat fungsional merupakan hal yang remeh dalam perancangan arsitektur Sesat Agung. Sebab demi melahirkan identitas baru, bobot arsitektur ditekan hingga sebatas estetika tanpa substansi. Jadi, masihkah kita berbicara tentang arsitektur? Sampai disini, peneliti berani menyimpulkan bahwa atribut yang melekat pada tubuh Sesat Agung sukses mereka ulang pesona arsitektur Nusantara, namun gagal menembus dimensi hakikat akan sebuah pernaungan. Arsitektur Sesat Agung hanyalah keindahan yang bersifat sesaat, seperti bunga tidur di siang bolong.

\section{DAFTAR PUSTAKA}

Ching, F. D. (1979). Architecture: Form, Space, and Order. Wiley.

Krier, R. (1988). Architectural Composition. London: Rizzoli.

Muchamad, B. N., \& Ikaputra. (2010). Model Ekspresi Arsitektur. Seminar Nasional "Metodologi Riset dalam Arsitektur", 39-45.

Prijotomo, J. (2008). Pasang Surut Arsitektur Indonesia. Surabaya: Wastu Lanas Grafika.

Prijotomo, J. (2018). Prijotomo membenahi arsitektur Nusantara. Surabaya: Wastu Lanas Grafika.

Prijotomo, J. (2019). Omo-Uma-Ume-Omah, Jelajah Arsitektur Nusantara yang Belum Usai. Surabaya: Wastu Lanas Grafika.

Rusdi, U. (1986). Arsitektur Tradisional Daerah Lampung. Jakarta: Departemen Pendidikan dan Kebudayaan.

Salura, P. (2018). Anatomy of architecture based on the creation of space for activity. International Journal of Engineering \& Technology, 7(2.14), 205-207.

Salura, P. (2018). The Philosophy of Architectural Ordering Principles. International Journal of Engineering and Technology (UAE) 7 (2), 52-55.

Schodek, D. L. (2001). Structures. Upper Saddle River, N.J: Prentice Hall. 